\title{
Structural brain changes associated with antipsychotic treatment in schizophrenia as revealed by voxel-based morphometric MRI: an activation likelihood estimation meta-analysis
}

\author{
Ulysses S Torres ${ }^{1,2,3^{*}}$, Eduardo Portela-Oliveira ${ }^{4}$, Stefan Borgwardt ${ }^{5,6}$ and Geraldo F Busatto ${ }^{1,2,3}$
}

\begin{abstract}
Background: The results of multiple studies on the association between antipsychotic use and structural brain changes in schizophrenia have been assessed only in qualitative literature reviews to date. We aimed to perform a meta-analysis of voxel-based morphometry (VBM) studies on this association to quantitatively synthesize the findings of these studies.
\end{abstract}

Methods: A systematic computerized literature search was carried out through MEDLINE/PubMed, EMBASE, ISI Web of Science, SCOPUS and PsycINFO databases aiming to identify all VBM studies addressing this question and meeting predetermined inclusion criteria. All studies reporting coordinates representing foci of structural brain changes associated with antipsychotic use were meta-analyzed by using the activation likelihood estimation technique, currently the most sophisticated and best-validated tool for voxel-wise meta-analysis of neuroimaging studies.

Results: Ten studies (five cross-sectional and five longitudinal) met the inclusion criteria and comprised a total of 548 individuals (298 patients on antipsychotic drugs and 250 controls). Depending on the methodologies of the selected studies, the control groups included healthy subjects, drug-free patients, or the same patients evaluated repeatedly in longitudinal comparisons (i.e., serving as their own controls). A total of 102 foci associated with structural alterations were retrieved. The meta-analysis revealed seven clusters of areas with consistent structural brain changes in patients on antipsychotics compared to controls. The seven clusters included four areas of relative volumetric decrease in the left lateral temporal cortex [Brodmann area (BA) 20], left inferior frontal gyrus (BA 44), superior frontal gyrus extending to the left middle frontal gyrus (BA 6), and right rectal gyrus (BA 11), and three areas of relative volumetric increase in the left dorsal anterior cingulate cortex (BA 24), left ventral anterior cingulate cortex (BA 24) and right putamen.

Conclusions: Our results identify the specific brain regions where possible associations between antipsychotic drug usage and structural brain changes in schizophrenia patients are more consistently reported. Additional longitudinal VBM studies including larger and more homogeneous samples of schizophrenia patients may be needed to further disentangle such alterations from those possibly linked to the intrinsic pathological progressive process in schizophrenia.

Keywords: Schizophrenia, Antipsychotics, Voxel-based morphometry, Magnetic resonance imaging, Neuroimaging

\footnotetext{
*Correspondence: utorres@usp.br

${ }^{1}$ Post-Graduate Program in Radiology, Institute of Radiology (INRAD),

University of Sao Paulo Medical School, Sao Paulo, Brazil

${ }^{2}$ Laboratory of Neuroimaging in Psychiatry (LIM-21), Institute of Psychiatry,

University of Sao Paulo Medical School, Centro de Medicina Nuclear, $3^{\circ}$

andar, Rua Dr. Ovídio Pires Campos, s/n, 05403-010 Sao Paulo, Sao Paulo,

Brazil

Full list of author information is available at the end of the article
} 


\section{Background}

Schizophrenia is a common, complex and severe psychiatric disorder affecting approximately $1 \%$ of the world population. The disorder remains a major cause of chronic disability among young and working-age individuals and is associated with a significant health, social and economic burden internationally [1-4]. Whereas finding an etiology for schizophrenia has been considered the "Holy Grail" of biological psychiatry research for more than one hundred years [5,6], its neurobiological basis mostly remains elusive in terms of its major neuropathologic, pathophysiologic, psychopharmacologic and genetic aspects $[1,7]$.

In the last decades, with the advent of more sophisticated neuroimaging techniques such as magnetic resonance imaging (MRI), which allows in vivo studies of the brains of individuals with schizophrenia, structural brain changes in schizophrenia have been extensively characterized [8-10]. Some of these findings include smaller mean cerebral volumes and greater mean total ventricular volume in patients with schizophrenia, with significant decreases in both gray and white matter [11].

These findings initially have favored a dominant "neurodevelopmental" model of the origin of the disease: in the model, schizophrenia is basically a consequence of a disruption in early brain development, long before the clinical manifestations of disease that typically occur in adolescence or early adulthood. Moreover, an interaction between these early brain insults and environmental factors delineating the brain maturation in adolescence would be necessary to trigger psychotic behavior [7,12-17].

However, as these structural brain changes are often subtle and their course is difficult to appreciate in an evolving manner, it is only after robust and longitudinal MRI studies that the possibility of progressive structural brain changes over time has been strengthened (favoring the addition of a "neurodegenerative" hypothesis to the dominant "neurodevelopmental" model) [18-25]. The advent of voxel-based morphometry (VBM) was of crucial importance in this sense, as VBM represents an automated method of measuring whole-brain morphometry by comparing groups of images on the relative local concentration or density of gray or white matter in a voxel-by-voxel way, thus reducing investigator bias and providing highly reproducible results, among other benefits [26-28].

Although a neurodevelopmental insult does not preclude an associated neurodegenerative process [29], the idea of progressive structural changes in the brain over time, which could denote neurodegeneration, has been a controversial issue [30-32], particularly because the findings of different studies have at times seemed inconsistent. A notable example is the question of lateral ventricles: whereas some longitudinal MRI and CT studies showed no enlargement over time [33-35], others have shown significant progression [36]; a recent meta-analysis comprising 13 studies regarding this question identified evidence of a progressive ventricular enlargement, concluding that the exclusively neurodevelopmental model of schizophrenia is now challenged [30].

While the progressive nature of structural brain changes in schizophrenia is not yet fully understood, they are thought to be in some degree due to a combination of abnormalities of synaptic plasticity, abnormal brain maturation and distinct environmental factors [37]. For many years, although a significant number of individuals involved in neuroimaging studies had used antipsychotic drugs, the role of drug treatment as a cause of these changes has been scarcely investigated [38]. Thus, among the environmental factors, a major current question is the role of antipsychotic medications in the progression of structural abnormalities, i.e., to determine to what extent these global brain volume changes are uniquely a consequence of schizophrenia (a progressive pathophysiology of the illness) or an effect of antipsychotics (including the potentially different role of typical and atypical classes) [38-43].

Antipsychotic medications are the cornerstone of the treatment of schizophrenia and have a positive effect on the prognosis, not only by leading to a general improvement in the long-term outcomes of patients but also by reducing the severity and frequency of positive and negative psychotic symptoms, including suicide risk as well as behavioral disturbances [44-49]. Classical (typical) antipsychotics (e.g., haloperidol) predominantly act by blocking dopamine $D_{2}$ receptors in mesostriatal, mesolimbic and mesocortical regions and the thalamus, directly contributing to the amelioration of psychotic symptoms that are thought to be a result of abnormally increased dopaminergic activity in these pathways [50-53]. New-generation (atypical) antipsychotics (e.g., clozapine), despite their activity in reducing dopaminergic activity through dopamine D2 receptors blockade, have binding activity at various others receptors, including a higher affinity for the serotoninergic $5-\mathrm{HT}_{2 \mathrm{~A}}$ receptors (high $5-\mathrm{T}_{2 \mathrm{~A}} / \mathrm{D}_{2}$ binding ratio) involved in the treatment of positive and negative symptoms [53,54]. Although this differentiation has clinical relevance, especially with regard to distinct side-effect patterns, the mechanisms of action of these drugs are not yet fully understood, and the definition of atypicality remains a matter of discussion [53-55].

Neuroimaging has a potential role in research aimed at a better understanding of structural brain changes secondary to antipsychotic usage. In the last years, numerous studies have been undertaken to address these questions, involving variable subsets of schizophrenia patients with different disease duration, age of onset, time of exposition to antipsychotics and degrees of 
clinical severity [30,56,57]. In addition, an important limitation of most of these studies is the small sample size used [57], which decreases statistical power and limits more definitive conclusions. Finally, only a few studies have used the VBM approach [39,57]. All these aforementioned factors make data interpretation difficult, reinforcing the need for meta-analytic studies in this area using homogeneous morphometric methodologies and including multiple samples of patients.

A tool for voxel-wise meta-analysis of neuroimaging studies is the anatomic likelihood estimation technique (ALE). ALE incorporates multiple data sets of published coordinates generated by different VBM studies of a given disorder, automatically identifying through a whole-brain activation likelihood map those statistically significant (i.e., the most consistent) brain differences reported across these studies [58-60]. By avoiding the bias inherent in those studies employing manual ROIs and allowing the application of a statistical procedure, by depicting regional brain differences with good spatial resolution and by affording more definitive conclusions than single VBM studies, ALE is considered the most sophisticated and best-validated method of coordinatebased voxel-wise meta-analysis [61,62].

Although a number of well-written and comprehensive literature reviews have been conducted in recent years addressing the role of antipsychotics in the progression of structural brain changes over time in schizophrenia $[38,39,41,43]$, these approaches to date have been only qualitative. No published study to date has used the ALE quantitative approach to conduct meta-analyses of VBM investigations comparing schizophrenia patients on antipsychotics versus unmedicated patients and healthy controls, or comparing schizophrenia patients before and after antipsychotic usage. Considering that some VBM studies have investigated samples comprised of as few as 15 schizophrenia patients, it is timely to apply a metaanalytic approach addressing this question, to quantitatively synthesize the findings of different studies, thus affording greater statistical power through the use of larger samples.

In this study, therefore, we sought to quantitatively review the relevant literature on the association between antipsychotics and structural brain changes in schizophrenia through a meta-analytic approach of VBM studies by using the ALE method. By quantitatively integrating the different foci of structural changes reported in each study, our objective was to establish whether a consistent anatomical pattern across these reported foci can be observed and determine the clusters of significant topographic convergence, ultimately providing a neuroanatomical basis for these changes. We also questioned whether the meta-analytic approach might aid in differentiating between the effects of antipsychotics and those solely related to the disease itself. Alternatively, it might help to organize the data from distinct studies even without further clarifying this dilemma. In this sense, we hypothesized that the quantitative meta-analytic approach, by more consistently identifying the regions affected by antipsychotics, might help to delineate the regional patterns of brain involvement associated with antipsychotic medications and to verify the overlaps with the classical patterns of brain involvement associated with the pathophysiological process during the development of psychosis. The identification of areas of structural brain alterations associated with antipsychotic exposure that differ from those areas commonly associated with the disease would aid in achieving a better understanding of this question.

\section{Methods}

\section{Data sources and paper selection}

We conducted a systematic computerized literature search via the MEDLINE/PubMed (http://www.ncbi. nlm.nih.gov/pubmed), EMBASE (http://www.embase. com), ISI Web of Science (http://newisiknowledge.com/ wos), SCOPUS (http://www.scopus.com) and PsycINFO (http://www.apa.org/psycinfo) databases for VBM studies investigating the role of antipsychotic drugs in structural brain changes in samples of patients with schizophrenia. We used the following search keywords in different combinations to generate a list of potentially useful studies: "schizophrenia" (as well as variants, including "psychosis" and "schizoaffective"), crossed with "antipsychotics", "antipsychotic agents" or "neuroleptics" and neuroimaging stems, including "MRI", "magnetic resonance imaging", "VBM" and "voxel-based morphometry". The search was performed through August 2012, and no restrictions on date of publication or language were applied. We carefully examined all titles and abstracts resulting from these searches to determine which articles met the criteria for inclusion. The full text of all selected articles was evaluated, and the references for each article were also screened to identify additional eligible papers. All studies were obtained from peer-reviewed journals.

We selected studies considering the following inclusion criteria: a) original research articles; b) quantitative automated whole-brain analyses were performed; c) the VBM method was used [26,63]; c) the samples included subjects with schizophrenia using typical or atypical antipsychotics, and comparisons were performed with healthy controls or medication-free subjects, or schizophrenic patients were compared through serial MRI examinations both at baseline and after specific treatment with an antipsychotic; d) the results were normalized to the Talairach [64] or Montreal Neurological Institute (MNI) [65,66] standardized stereotactic spaces; e) after 
VBM analyses, the peak coordinates of structural brain changes specifically associated with antipsychotics (i.e., after controlling for confounding effects such as the effects of disease, disease duration, etc.) were explicitly reported. In cases where the coordinates were not reported, attempts were made to contact the corresponding author for further details (e-mail and phone contact). The PRISMA (Preferred Reporting Items for Systematic Reviews and Meta-Analyses) flowchart detailing all the steps of the systematic review is provided in Figure 1.

\section{Meta-analytic techniques}

As aforementioned, meta-analysis was carried out by using the ALE method as introduced by Turkeltaub in
2002 [58], with revision by Laird in 2005 [59], Eickhoff in 2009 [60] and Turkeltaub in 2011 [67]; data processing was performed through the GingerALE 2.1 program [59,60,67] (http://www.brainmap.org). The analyses were conducted in Talairach space [64], and, when necessary, we spatially renormalized the MNI coordinates $[65,66]$ published in some studies to Talairach coordinates [64], using the Lancaster's transform (“icbm2tal") $[68,69]$.

Briefly, ALE is a method that determines the existence of anatomical convergence among results from different samples and studies, assuming an uncertainty in the location of each reported focus, which should be considered in terms of Gaussian probability density distributions that surround themselves. Therefore, the focus of
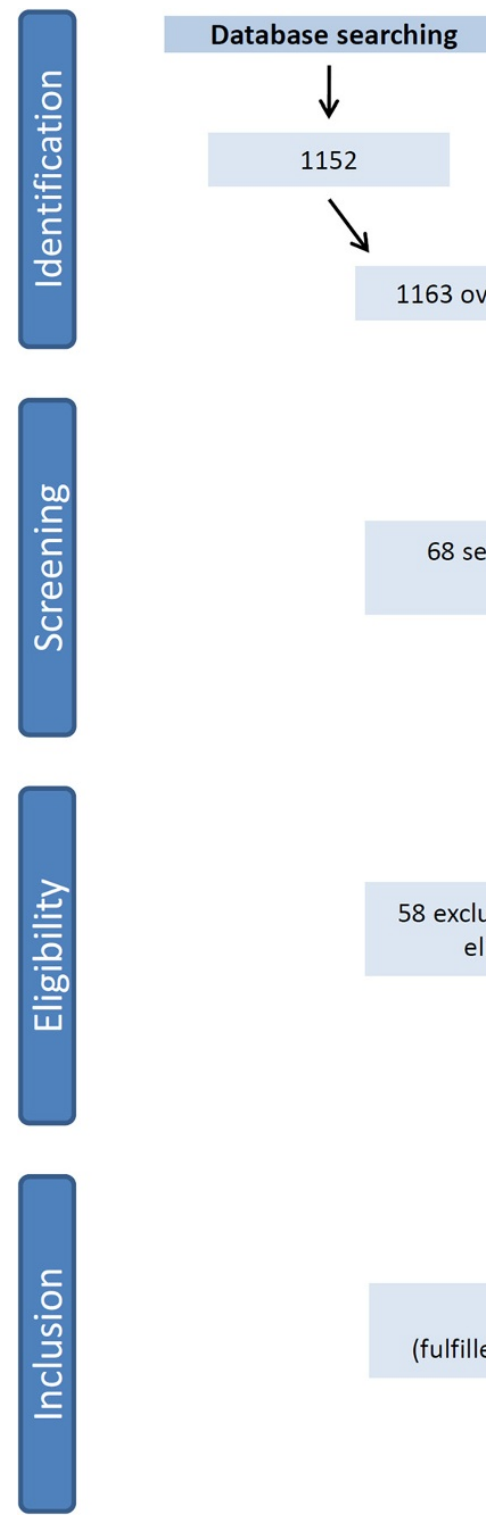

Hand-searching

1163 overall search results

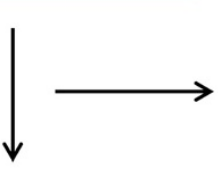

\section{Exclusion of duplicates}

Exclusion after assessment of titles and abstracts (irrelevance, non-schizophrenic patients, literature reviews, used

68 selected for full text assessment other volumetric methods rather than VBM as described in the abstract, etc.)

58 excluded for not fulfilling eligibility criteria

10 selected (fulfilled eligibility criteria)
Did not use VBM method (51)

Included only drug-naïve schizophrenia patients (3)

Did not find coordinates of significant brain volumetric changes

(2)

Found brain volumetric changes only on small volume-corrected analyses

(1)

Did not report coordinates of brain volumetric changes (1)

Figure 1 PRISMA flowchart of search results. 
maximal activation (peak coordinates) represents the center of a three-dimensional Gaussian probability [58]. As recently proposed in the revised ALE algorithm, the use of pre-determined full-width half maximum (FWHM) values for the Gaussian probability distributions in the analyses is no longer required. The values are now empirically determined on the basis of a quantitative uncertainty model whereby the coordinates reported by studies with larger samples are more spatially accurate than those from smaller ones, thus requiring smaller FWHM values [60].

As ALE seeks to determine statistically significant convergence of activation probabilities between experiments, refuting the null hypothesis that the foci are homogeneously distributed throughout the brain [70], the modeled three-dimensional Gaussian probabilities of all foci reported in each experiment are summed in a voxel-wise manner, resulting in modeled activation (MA) maps $[60,70]$. The voxel-wise union of each computed MA map yields the "true ALE scores", which demonstrate the convergence of foci through the whole brain across the entire set of studies. Permutation analyses conducted in ALE meta-analyses (using GingerALE, for example) are anatomically unconstrained, including not only the predominant foci within gray matter but also the foci within the deep white matter. Thus, it is a whole-brain analysis that allows conjoint analysis of gray and white matter foci. Finally, to determine the statistical significance, i.e., to assess the validity of convergence found in the true ALE scores over a random convergence (noise), an automated comparison is performed with a computed empirical null distribution of random ALE scores. For this purpose, from each MA map, a voxel is randomly selected and its probability is computed, and the union of these probabilities (as done for the true scores) yields the random score [60].

As described in previous meta-analyses of VBM studies, we adopted a threshold for the map of final ALE scores with a false discovery rate (FDR) corrected at $\mathrm{p}<$ 0.05 [71-73] and a cluster extent threshold of $100 \mathrm{~mm}^{3}$ $[72,74]$. In addition, we chose the resultant coordinates to be reported for all submaxima in a single ALE cluster (all extrema). Significant clusters were overlaid onto an anatomical Talairach template, Colin1.1.nii (http://www. brainmap.org/ale), using the Mango software (version 2.6, 2012, Research Imaging Institute, University of Texas Health Science Center, USA; http://ric.uthscsa. edu/mango).

\section{Results}

The systematic search yielded 1163 abstracts, of which 68 were initially selected for a full-text screening. One study, by Massana et al. [75], was excluded, as the stereotactic coordinates were not reported in the paper nor provided by the authors after request (personal communication). Another study, by Schaulfelberger et al. [76], was excluded because significant peak coordinates of structural brain changes were found only with small volume correction analysis.

Finally, ten studies [77-86] met the inclusion criteria (PRISMA flowchart in Figure 1). Additional data were necessary for the maps and peak coordinates reported in the study by Molina et al. [86] and were provided by the authors after submitting a request via e-mail (personal communication). Table 1 illustrates the clinical and demographic variables of the subjects included in the ten selected studies, which encompassed a total of 548 individuals (298 patients using typical or atypical antipsychotics and 250 controls). For the effect of reported coordinates included in this meta-analysis, five selected studies were classified as longitudinal $[78,79,81,82,84]$ and five as cross-sectional $[77,80,83,85,86]$. Table 2 provides details on the methodologies of each selected study.

Most of the patients enrolled were using atypical antipsychotics (234; 78.5\%), which in these samples included olanzapine, risperidone, quetiapine, sertindole, amisulpiride, clozapine and ziprasidone. From the subset of studies which specifically described the number of patients who had taken each antipsychotic [77,78,80,82-86], olanzapine and risperidone were the most frequently used drugs among these 179 patients treated with atypicals, being used for $40.7 \%$ (73) and $30.1 \%$ (54) of the patients, respectively. Typical antipsychotics used when considering all the selected studies were chlorpromazine, sulpiride, haloperidol, thioridazine, droperidol, trifluoperazine, zuclopenthixol, fluphenazine and clotiapine. Additional file 1 summarizes the data concerning the antipsychotic drugs used by the patients of these selected studies.

Overall, 105 foci were retrieved in the analysis of the ten studies, 71 of which were related to volumetric gray matter and/or white matter deficits, and 34 to volumetric excesses. Additional file 2 demonstrates in the stereotactic space the foci of reported structural brain changes according to the class of antipsychotics (when available) and the type of alteration in the meta-analyzed studies. As some of the selected studies showed different effects for the use of antipsychotics, i.e., showed areas of both volumetric excesses and volumetric deficits, the metaanalysis was performed separately for those coordinates related to volumetric deficits and for those related to volumetric excesses. Patients using antipsychotic medications had four significant clusters of volumetric deficits in comparison to controls: 1) a cluster of $408 \mathrm{~mm}^{3}$ located in the left lateral temporal cortex, BA 20 (peak voxel at Talairach coordinate $-48,-16,-20)$; 2) a cluster of $192 \mathrm{~mm}^{3}$ located in the left inferior frontal gyrus, BA 44 (peak voxel at Talairach coordinate $-48,6,22$ ); 3 ) a cluster of $120 \mathrm{~mm}^{3}$ located in the left superior frontal 
Table 1 Clinical and demographical data from subjects included in the selected studies

\begin{tabular}{|c|c|c|c|c|c|c|c|c|c|c|c|}
\hline \multirow[t]{3}{*}{ Reference } & \multicolumn{6}{|c|}{ Subjects $(n)$} & \multirow{3}{*}{$\begin{array}{l}\text { Gender of } \\
\text { patients (F/M) }\end{array}$} & \multirow{3}{*}{$\begin{array}{l}\text { Age of } \\
\text { patients } \\
\text { (years) }^{\mathrm{a}}\end{array}$} & \multirow{3}{*}{$\begin{array}{l}\text { Education } \\
\text { (years) }^{\mathrm{a}}\end{array}$} & \multirow{3}{*}{$\begin{array}{l}\text { Duration of } \\
\text { illness }\end{array}$} & \multirow{3}{*}{$\begin{array}{l}\text { Handedness } \\
\text { (R/L/A) }\end{array}$} \\
\hline & \multicolumn{2}{|c|}{ Patients } & \multicolumn{3}{|c|}{ Controls } & \multirow[t]{2}{*}{ Total } & & & & & \\
\hline & Typical & Atypical & $\begin{array}{l}\text { Healthy } \\
\text { subjects* }\end{array}$ & SP & MF & & & & & & \\
\hline $\begin{array}{l}\text { Dazzan et al. } \\
2005 \text { [77] }\end{array}$ & 32 & 30 & - & - & 22 & 84 & $21 / 41$ & $\begin{array}{l}25 \pm 8 \text { to } 28.4 \\
\pm 7.8\end{array}$ & $\begin{array}{l}12.3 \pm 1.8 \text { to } \\
12.3 \pm 2.1\end{array}$ & $\begin{array}{l}19 \text { to } 22 \\
\text { weeks }^{\mathrm{b}}\end{array}$ & $54 / 8$ \\
\hline $\begin{array}{l}\text { Girgis et al. } \\
2006 \text { [78] }\end{array}$ & - & 15 & 15 & 15 & - & 30 & $8 / 7$ & $23.6 \pm 5.9$ & $13.1 \pm 3.2$ & $\begin{array}{l}105.3 \pm 94.6 \\
\text { weeks }\end{array}$ & NA \\
\hline $\begin{array}{l}\text { Whitford et al. } \\
2006 \text { [79] }\end{array}$ & - & 25 & 26 & 25 & - & 51 & $10 / 15$ & $22.1 \pm 3.2$ & NA & $\begin{array}{l}5.9 \pm 8.2 \\
\text { months }^{a}\end{array}$ & $21 / 4$ \\
\hline $\begin{array}{l}\text { Douaud et al. } \\
2007 \text { [80] }\end{array}$ & - & 25 & 25 & - & - & 50 & $7 / 18$ & $\begin{array}{l}15.9 \pm 1.5 \text { to } \\
16.5 \pm 1.3\end{array}$ & NA & $\begin{array}{l}1.4 \pm 0.7 \\
\text { year }^{\mathrm{a}}\end{array}$ & $20 / 5$ \\
\hline $\begin{array}{l}\text { Théberge et al. } \\
2007 \text { [81] }\end{array}$ & 16 & & 16 & 16 & - & 32 & $2 / 14$ & $25 \pm 8$ & $11-13$ & $\begin{array}{l}243 \pm 120 \\
\text { weeks }^{\mathrm{a}}\end{array}$ & $12 / 3 / 1$ \\
\hline $\begin{array}{l}\text { Stip et al. } \\
2009 \text { [82] }\end{array}$ & - & 15 & - & 15 & - & 15 & $4 / 11$ & $28.3 \pm 9.07$ & $10.6 \pm 3.5$ & $\begin{array}{l}5.8 \pm 6.2 \\
\text { years }^{\mathrm{a}}\end{array}$ & NA \\
\hline $\begin{array}{l}\text { Tomelleri et al. } \\
2009 \text { [83] }\end{array}$ & 25 & 45 & 79 & - & - & 149 & $25 / 45$ & $39.73 \pm 10.94$ & NA & $\begin{array}{l}14.13 \pm 10.7 \\
\text { years }\end{array}$ & $67 / 3$ \\
\hline $\begin{array}{l}\text { Deng et al. } \\
2009 \text { [84] }\end{array}$ & 6 & 14 & 11 & - & - & 31 & $11 / 9$ & $\begin{array}{l}26 \pm 10 \text { to } 29.9 \\
\pm 13.5\end{array}$ & NA & NA & $18 / 2$ \\
\hline $\begin{array}{l}\text { Chua et al. } \\
2009 \text { [85] }\end{array}$ & 15 & 5 & - & - & 25 & 45 & $10 / 10$ & $29 \pm 8.6$ & $12 \pm 2.9$ & $\begin{array}{l}40.8 \pm 50.8 \\
\text { weeks }^{\mathrm{a}}\end{array}$ & NA \\
\hline $\begin{array}{l}\text { Molina et al. } \\
2011 \text { [86] }\end{array}$ & - & 30 & 31 & - & - & 61 & $14 / 16$ & $34.1 \pm 10.6$ & NA & $\begin{array}{l}13.4 \pm 5.9 \\
\text { years }\end{array}$ & NA \\
\hline
\end{tabular}

*Matched for age and gender to the patients groups; $a=$ mean $\pm S D ; b=$ median $( \pm S D) ; N A=$ data not available; $S P=$ same patients evaluated repeatedly in longitudinal comparisons; MF = medication-free subjects.

gyrus, extending to the left middle frontal gyrus, BA 6 (peak voxel at Talairach coordinate $-22,12,48$ ); and 4) a cluster of $104 \mathrm{~mm}^{3}$ located in the right rectal gyrus, BA 11 (peak voxel at Talairach coordinate 4, 38, -24). In addition, patients using antipsychotic medications also had three significant clusters of volumetric excesses in comparison to controls: 1) a cluster of $416 \mathrm{~mm}^{3}$ located in the left dorsal anterior cingulate cortex, BA 24 (peak voxel at Talairach coordinate $-2,24,6)$; 2) a cluster of $152 \mathrm{~mm}^{3}$ located in the left ventral anterior cingulate cortex, BA 24 (peak voxel at Talairach coordinate -4, 2, $26)$; and 3) a cluster of $264 \mathrm{~mm}^{3}$ located in the right putamen (peak voxel at Talairach coordinate $24,-4,4$ ). The final maps with the resultant significant areas of volumetric deficits and excesses in patients using antipsychotics through the selected studies are displayed in Figures 2 and 3, respectively.

We also conducted sub-analyses comparing the effects of typical and atypical antipsychotics. Three studies did not report peak coordinates according to typicality and were excluded from these sub-analyses [81,84,85]. Volumetric decreases with typicals were found in only one study [77], and thus these foci could not be metaanalyzed. Volumetric increases with typicals were found in two studies $[77,83]$, but no significant clusters were found. Volumetric decreases with atypicals were reported in three studies $[79,80,86]$, retrieving one significant cluster of $456 \mathrm{~mm}^{3}$ located in the left temporal lobe, BA 20 (peak voxel at Talairach coordinate $-48,-16-,-20)$. Finally, volumetric increases with atypicals were reported in five studies [77,78,82,83,87], retrieving two significant clusters: 1) a cluster of $160 \mathrm{~mm}^{3}$ located in the right putamen (peak voxel at Talairach coordinate 26, -10, 8); and 2) a cluster of $112 \mathrm{~mm}^{3}$ located in the left thalamus (peak voxel at Talairach coordinate $-2,-26,4)$.

\section{Discussion}

Among the several variables that could possibly determine or contribute to the brain structural changes observed in patients with schizophrenia in the numerous neuroimaging studies performed in recent years - including those specifically related to the illness (age of onset, duration, severity) and the individual (age, gender, scholarity) - it is the role of antipsychotics that remains a critical question, although possibly still beyond a definitive answer.

A relatively low number of studies have addressed this issue, which is made more difficult by the complex task of harmonizing or balancing the effects of all the other possible variables, and by the crucial necessity of more homogeneous samples of patients, not only with respect to the variables related to the illness and individuals but also to those related to antipsychotics (class, years of 
Table 2 Summary of the methodologies used for each selected study

\begin{tabular}{|c|c|c|c|c|c|c|c|c|}
\hline Reference & Design & Methods & $\begin{array}{l}\text { Stereotactic } \\
\text { space }\end{array}$ & $\begin{array}{l}\text { Statistical } \\
\text { threshold }\end{array}$ & $\begin{array}{l}\text { Full-width } \\
\text { half-maximum } \\
\text { kernel }\end{array}$ & $\begin{array}{l}\text { Type of } \\
\text { analysis }\end{array}$ & $P$ value & Controlling for \\
\hline $\begin{array}{l}\text { Dazzan } \\
\text { et al. } \\
2005 \text { [77] }\end{array}$ & $\begin{array}{l}\text { Cross- } \\
\text { sectional }\end{array}$ & $\begin{array}{l}\text { Comparison of subjects } \\
\text { using typical and atypical } \\
\text { antipsychotics versus } \\
\text { drug-free patients }\end{array}$ & Talairach & Corr & NA & $\begin{array}{l}\text { Whole- } \\
\text { brain } \\
\text { analysis }\end{array}$ & $\begin{array}{l}P \\
\leq 0.002\end{array}$ & $\begin{array}{l}\text { Age, gender, duration of } \\
\text { illness, total symptom } \\
\text { scores, length of } \\
\text { treatment, premorbid IQ, } \\
\text { years of education }\end{array}$ \\
\hline $\begin{array}{l}\text { Girgis } \\
\text { et al. } \\
2006 \text { [78] }\end{array}$ & Longitudinal & $\begin{array}{l}\text { Comparison between } \\
\text { patients using atypical } \\
\text { antipsychotics (from baseline } \\
\text { to 6-week follow-up) versus } \\
\text { healthy controls }\end{array}$ & Talairach & Unc & $12 \mathrm{~mm}$ & $\begin{array}{l}\text { Whole- } \\
\text { brain } \\
\text { analysis }\end{array}$ & $\begin{array}{l}P \\
\leq 0.001\end{array}$ & $\begin{array}{l}\text { Age, gender, follow-up } \\
\text { interval, years of educa- } \\
\text { tion, socioeconomic } \\
\text { status, duration of illness, } \\
\text { total symptom scores }\end{array}$ \\
\hline $\begin{array}{l}\text { Whitford } \\
\text { et al. } \\
2006 \text { [79] }\end{array}$ & Longitudinal & $\begin{array}{l}\text { Comparison between } \\
\text { patients using atypical } \\
\text { antipsychotics } \\
\text { (at first episode psychosis } \\
\text { and at 2-3-year follow-up) } \\
\text { versus healthy controls }\end{array}$ & Talairach & Corr & $12 \mathrm{~mm}$ & $\begin{array}{l}\text { Whole- } \\
\text { brain } \\
\text { analysis }\end{array}$ & $\begin{array}{l}\mathrm{P}< \\
0.05\end{array}$ & $\begin{array}{l}\text { Age, gender, handedness, } \\
\text { follow-up interval }\end{array}$ \\
\hline $\begin{array}{l}\text { Douaud } \\
\text { et al. } \\
2007 \text { [80] }\end{array}$ & $\begin{array}{l}\text { Cross- } \\
\text { sectional }\end{array}$ & $\begin{array}{l}\text { Comparison of subjects using } \\
\text { atypical antipsychotics versus } \\
\text { healthy controls }\end{array}$ & $\mathrm{MNI}$ & Corr & $8 \mathrm{~mm}$ & $\begin{array}{l}\text { Whole- } \\
\text { brain } \\
\text { analysis }\end{array}$ & $\begin{array}{l}P< \\
0.01\end{array}$ & $\begin{array}{l}\text { Age, gender, handedness, } \\
\text { socioeconomic status }\end{array}$ \\
\hline $\begin{array}{l}\text { Théberge } \\
\text { et al. } \\
2007 \text { [81] }\end{array}$ & Longitudinal & $\begin{array}{l}\text { Comparison between } \\
\text { patients using antipsychotics } \\
\text { (at first episode psychosis } \\
\text { and at } 30 \text {-month follow-up) } \\
\text { versus healthy controls }\end{array}$ & Talairach & Corr & $12 \mathrm{~mm}$ & $\begin{array}{l}\text { Whole- } \\
\text { brain } \\
\text { analysis }\end{array}$ & $\begin{array}{l}P \\
<0.001\end{array}$ & $\begin{array}{l}\text { Age, gender, handedness, } \\
\text { parental education }\end{array}$ \\
\hline $\begin{array}{l}\text { Stip et al. } \\
2009[82]\end{array}$ & Longitudinal & $\begin{array}{l}\text { Comparison between } \\
\text { patients using atypical } \\
\text { antipsychotics at baseline } \\
\text { and at 5.5-month follow-up }\end{array}$ & $\mathrm{MNI}$ & Corr & $8 \mathrm{~mm}$ & $\begin{array}{l}\text { Whole- } \\
\text { brain } \\
\text { analysis }\end{array}$ & $\begin{array}{l}P< \\
0.01\end{array}$ & Non specified \\
\hline $\begin{array}{l}\text { Tomelleri } \\
\text { et al. } \\
2009 \text { [83] }\end{array}$ & $\begin{array}{l}\text { Cross- } \\
\text { sectional }\end{array}$ & $\begin{array}{l}\text { Comparison of subjects using } \\
\text { atypical and typical } \\
\text { antipsychotics versus healthy } \\
\text { controls }\end{array}$ & Talairach & Corr & $12 \mathrm{~mm}$ & $\begin{array}{l}\text { Whole- } \\
\text { brain } \\
\text { analysis }\end{array}$ & $\begin{array}{l}P< \\
0.01\end{array}$ & $\begin{array}{l}\text { Gender, duration of illness, } \\
\text { total symptom scores }\end{array}$ \\
\hline $\begin{array}{l}\text { Deng } \\
\text { et al. } \\
2009 \text { [84] }\end{array}$ & Longitudinal & $\begin{array}{l}\text { Comparison between } \\
\text { patients using atypical and } \\
\text { typical antipsychotics (from } \\
\text { baseline to 8-week follow-up) } \\
\text { versus healthy controls }\end{array}$ & $\mathrm{MNI}$ & Unc & $8 \mathrm{~mm}$ & $\begin{array}{l}\text { Whole- } \\
\text { brain } \\
\text { analysis }\end{array}$ & $p<0.001$ & $\begin{array}{l}\text { Age, gender, height, } \\
\text { handedness }\end{array}$ \\
\hline $\begin{array}{l}\text { Chua } \\
\text { et al. } \\
2009 \text { [85] }\end{array}$ & $\begin{array}{l}\text { Cross- } \\
\text { sectional }\end{array}$ & $\begin{array}{l}\text { Comparison of subjects using } \\
\text { atypical and typical } \\
\text { antipsychotics versus drug- } \\
\text { free patients }\end{array}$ & Talairach & Corr & $4.4 \mathrm{~mm}$ & $\begin{array}{l}\text { Whole- } \\
\text { brain } \\
\text { analysis }\end{array}$ & $p<0.002$ & $\begin{array}{l}\text { Age, gender, handedness, } \\
\text { ethnicity, height, years of } \\
\text { education, paternal socio- } \\
\text { economic status, total } \\
\text { symptom scores }\end{array}$ \\
\hline $\begin{array}{l}\text { Molina } \\
\text { et al. } \\
2011[86]\end{array}$ & $\begin{array}{l}\text { Cross- } \\
\text { sectional }\end{array}$ & $\begin{array}{l}\text { Comparison of subjects using } \\
\text { atypical antipsychotics versus } \\
\text { healthy controls }\end{array}$ & Talairach & Corr & NA & $\begin{array}{l}\text { Whole- } \\
\text { brain } \\
\text { analysis }\end{array}$ & $p<0.05$ & $\begin{array}{l}\text { Age, gender, parental } \\
\text { socioeconomic status, } \\
\text { duration of illness }\end{array}$ \\
\hline
\end{tabular}

Corr = corrected for multiple comparisons; Unc = uncorrected for multiple comparisons.

exposure, dosages, withdrawals). Indeed, the additional difficulty of recruiting subjects with a psychiatric disease that has a low prevalence rate [88] has led to studies with relatively small numbers of patients. Considering also that the volumetric structural brain alterations in schizophrenia are often very subtle, thus requiring large samples to sufficiently increase the statistical power that would allow for the detection of such alterations [88], it is not surprising that sometimes the results of these distinct studies are somewhat confusing or even contradictory $[38,39,41,43]$.
Whereas studies on the progression of structural brain changes in schizophrenia over time have been consistently replicated through recent years, as previously addressed in the introduction, studies on the role of antipsychotics have been presenting results ranging from brain volumetric reductions [89] to "no effect" [90] to volumetric enlargement [91], for example. Evidence from studies including larger samples of subjects, however, suggests a progressive correlation between brain volumetric reduction and antipsychotic use. In a multi-site 


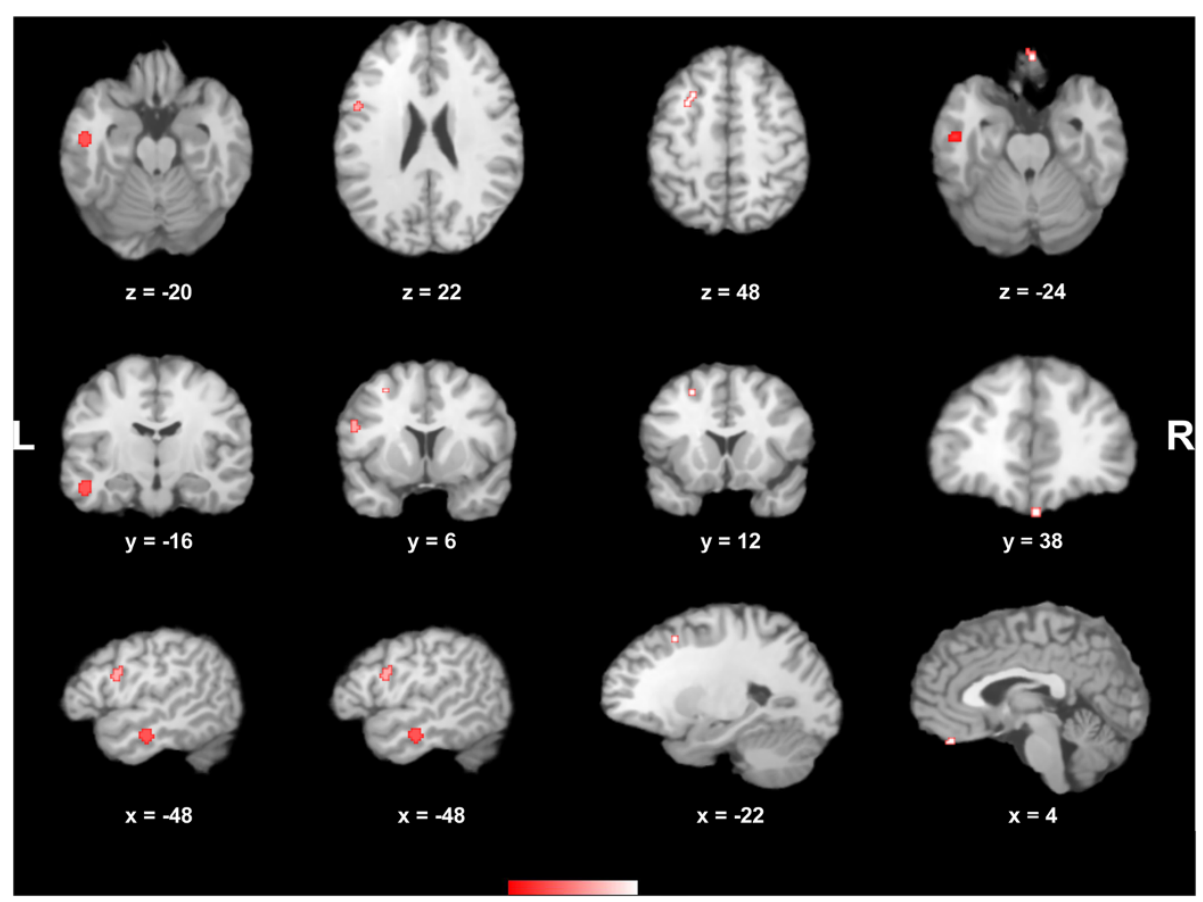

Figure 2 Areas of statistically significant brain volumetric decreases across the selected studies (displayed in the axial, coronal and sagittal plans) in patients with schizophrenia receiving antipsychotic medications. Peak coordinates $\left(x_{i} y_{i} z\right)$ in the Talairach stereotactic space are presented. $L$ left; $R$ right.

longitudinal randomized study carried out with 161 first-episode psychosis patients and 62 healthy controls, Lieberman et al. [92] allocated patients, after a baseline MRI scan and subsequent randomization, to haloperidol or olanzapine groups; they found that patients using haloperidol had a significant grey matter reduction after 12 and 52 weeks in comparison to controls, whereas olanzapine patients did not. Also Cahn et al. [89] prospectively studied 34 first-episode schizophrenia patients (who had taken antipsychotics for up to 16 weeks) and 36 healthy controls who underwent an MRI scan at admission and after 1 year; a higher cumulative dosage of antipsychotics (typicals and atypicals were used in the study) was significantly and independently correlated with total brain volume and gray matter volume reductions, as well as increased volume of lateral ventricles. A longitudinal study by Nakamura et al. [93] (29 firstepisode schizophrenia patients, 34 first-episode affective psychosis and 26 healthy controls) showed that schizophrenia patients had smaller gray matter volumes and larger sulcal cerebrospinal fluid and lateral ventricles in comparison to controls. Jayakumar et al. [94] studied 18 antipsychotic-naïve schizophrenia patients and 18 healthy controls; results showed gray-matter volumetric reductions and larger cerebrospinal fluid volumes, as also observed by Davatzikos et al. [95] (32 first-episode neuroleptic-naïve schizophrenia patients, 37 patients treated with antipsychotics and 79 controls). Conversely, some studies on this question have not found significant structural brain changes (volumetric reductions or excesses) when comparing patients and controls. Studies with large samples, for example, such as those by Molina et al. [87] (16 schizophrenia patients and 42 healthy controls), Tauscher-Wisniewski et al. [96] (37 first-episode patients and 37 controls), and Puri et al. [97] (24 firstepisode patients and 12 controls), did not identify significant volumetric differences. Recently, Ho et al. [98] performed a large longitudinal MRI study that followed 211 schizophrenia patients over a mean of 7.2 years, aiming to assess four potential variables (illness duration, illness severity, use of antipsychotics and substance abuse) that could have an effect on brain volumes. The authors found that even considering the effects of the other three variables, after statistical controlling, there was still a relationship between the amount of exposure to antipsychotics and brain volumetric reductions. Interestingly, these brain volumetric changes were not solely related to a specific antipsychotic class, but were observed both with typicals and atypicals [98].

The distinct pattern of effects on the brain induced either by typical or atypical drugs was a matter of discussion in some literature reviews, which showed that volumetric brain changes are more related to typicals than atypicals $[39,41]$. Another review, however, concluded that the literature on structural brain changes and antipsychotic effects is inconsistent (as about half of 


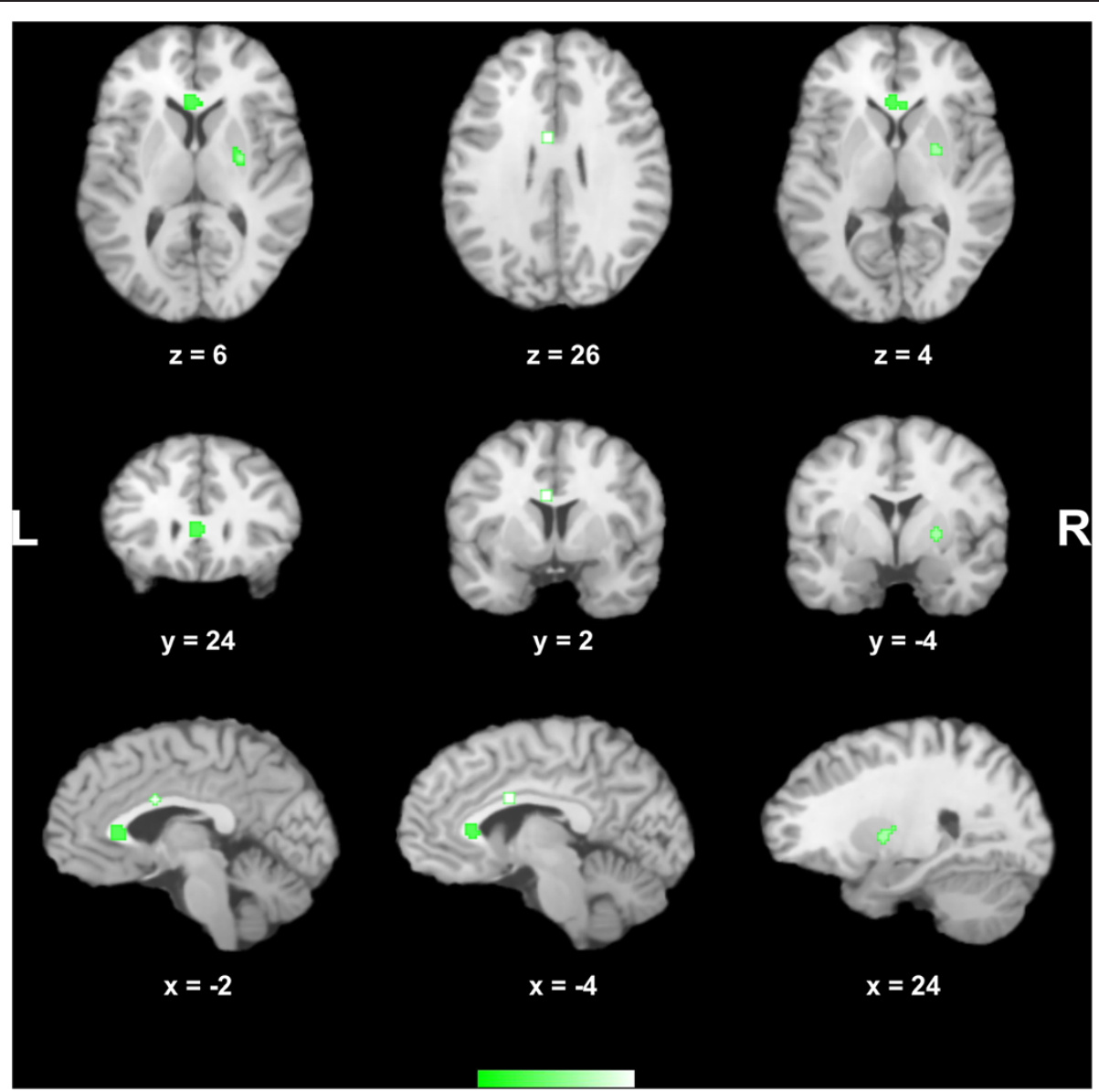

Figure 3 Areas of statistically significant brain volumetric increases across the selected studies (displayed in the axial, coronal and sagittal plans) in patients with schizophrenia receiving antipsychotic medications. Peak coordinates $(x ; y ; z)$ in the Talairach stereotactic space are presented. $L$ left; $R$ right.

the longitudinal studies did not find or report progressive brain changes), and the distinct patterns of effects determined by typicals or atypicals were inconsistent as well [38].

To the best of our knowledge, this is the first study to quantitatively assess with a meta-analytic approach the question of structural brain changes and antipsychotic use in schizophrenia by reviewing those studies which directly assessed this question. In 2011, Leung et al. [71] published a meta-analysis of VBM studies using the ALE method to detect antipsychotic-related gray-matter alterations in first-episode schizophrenia patients; however, in contrast to our study, these authors employed an indirect approach, by using subtraction analysis to compare structural brain changes between two separate subsets of meta-analyzed studies, i.e., a subset of studies involving neuroleptic-naïve first-episode schizophrenia patients and another subset of studies involving neuroleptic-treated first-episode schizophrenia patients. Additionally, literature reviews have hitherto been only qualitative, encompassing a large variety of studies carried out through distinct methodologies concerning volume measurement techniques.

The chosen voxel-wise approach using the ALE method confers at least one special advantage over previous reviews, which is the homogeneity of techniques employed by the selected studies regarding volumetry (i.e., the VBM method). Our results revealed a consistent volumetric reduction across the selected studies in the left temporal and frontal lobes, all of them being previously implicated areas reported to be of significance in studies involving patients with schizophrenia and first-episode psychosis [10,25,56,99-104]. Indeed, there is, for example, a body of evidence in the literature associating typical antipsychotics and also risperidone with decreased frontal metabolism in schizophrenia patients [105-108]. In the study by Leung et al. [71], subtraction analysis between the neuroleptic-treated and neuroleptic-naïve groups of first-episode psychosis patients revealed more extensive gray matter volumetric deficits in neuroleptic-treated patients in bilateral insula, medial frontal and inferior frontal gyrus, left parahippocampal 
gyrus, superior temporal gyrus and right precentral gyrus; of interest, while there were significant gray matter deficits in the frontal lobe of neuroleptic-naïve patients (a finding not related to drug exposure), treated patients also showed still more extensive frontal volumetric reductions, which notes a possible overlapping between the disease-related structural alterations and the effects of antipsychotics.

Another point of interest is the question of volumetric excesses. The finding of volumetric increases in subcortical regions (and in basal ganglia, more specifically) is widely described in the ROI literature and thought to be related to dopaminergic blockade [39] and increased striatal blood flow [109]. Antipsychotic-related increased volumes in the putamen, nucleus caudatus, globus pallidus and thalamus were found in several studies in the literature, both among typicals and atypicals, even after few weeks of treatment [39]. In previously neurolepticnaïve patients treated with atypicals, however, these basal ganglia alterations are not usually described [39], and atypicals seem to even reverse this effect after patients switch to them $[39,43]$. In this meta-analysis, the findings of volumetric excesses were observed across studies employing mainly atypical [77,78,82,83,86] but also typical antipsychotics $[77,83]$. Significant volumetric increases were observed in the cingulate gyrus and putamen, in concordance with some previous findings in the literature. Cumulative exposure to typical antipsychotics, for example, has been associated with a larger cingulate gyrus, an important region for the pathophysiology of schizophrenia [110-112]. McCormick et al. found an increase in anterior cingulate volume with use of typicals after 2-3 years in previously neuroleptic-naïve subjects; increased atypical medication exposure, in contrast, was correlated to decreased anterior cingulate volume [112]. Kopelman et al. also found greater anterior cingulate cortex volumes directly related to typical medication exposure [113]. This follows the same pattern of findings reported in regard to changes in the volume of basal ganglia structures [112], and these similarities may be related to the fact that the anterior cingulate cortex and basal ganglia are structurally and functionally connected, both structures receiving direct dopaminergic innervation from the ventral tegmental area and the substantia nigra [112]. In addition, the reported antipsychoticinduced hypertrophy in putamen, thalamus and caudate nucleus (observed both with typicals and atypicals) may also be related to changes in the synaptic organization of these D2 receptor-rich areas [84,86]. Indeed, the results of our sub-analysis carried out with atypical antipsychotics are in concordance with these findings, indicating significant volumetric increases in the thalamus and putamen.

In considering the results of this meta-analysis, we have to acknowledge a number of limitations. The main limitation concerns the challenge faced by all the selected studies in this field, which is the difficulty of disentangling the effects of drug treatment from those related to the underlying pathology; the results of various studies on this topic allow us currently only to make hypotheses, without reaching definitive conclusions, as is summarized in the last literature reviews [38,39,41,43]. In addition, ethical issues preclude more insightful study designs involving, for example, placebo-treated individuals with schizophrenia and antipsychotic-exposed healthy controls because there is no therapeutic benefit to justify the exposure of a healthy population to the effects of antipsychotics. Thus, we acknowledge that the results currently available in the literature are merely associative and inferential, and they do not necessarily imply causality. Independent of such facts, however, it should be noted that the current study does not intend primarily to question the internal validity of each published work reporting that these changes might be associated to antipsychotics; despite any concerns, these studies point to a possible association, and, methodologically, they represent the best that the current literature has to offer.

Yet, despite the strictness of the eligibility criteria that we applied, which led to a low number of selected studies, other limitations relate to the heterogeneity of search space (variability both in type of antipsychotic examined and in study designs). However, we aimed with this study to establish whether there were clusters of significant topographic convergence of structural brain changes reported in the selected VBM studies, independent of their designs. It is also possible that some factors (such as smoothing kernel, absence of correction for multiple comparisons and cluster size thresholds) that vary across different VBM studies may exert an influence on the final coordinates generated in each study, thus also affecting the results of ALE meta-analyses [71]. It is important to emphasize, however, that the revised ALE algorithm employed in this meta-analysis accounts for the inter-subject and interlaboratory variability observed in neuroimaging experiments, also employing a null distribution of spatial independence across studies [70].

Due to the limited reported data, we could not control for the effect of potential moderators such as illness duration and illness severity. However, the relatively large overall sample size, combined with strict quality control, yielded a robust meta-analytical approach. Additionally, when meta-analyzing the available foci according to the class of antipsychotics or type of study design in relation to the resultant brain effect (i.e., volumetric excesses, volumetric decreases), excessive fragmentation of the data prevented the findings of significant foci of convergence with typicals. Notably, however, there is currently no clear evidence regarding the effects of typicality on 
brain regional changes associated with antipsychotics in schizophrenia $[38,98]$.

Other limitations are related to the ALE method, as only those studies reporting peak coordinates can be incorporated into the meta-analysis; thus, those studies that found no significant differences between patients and controls (and consequently did not report peak coordinates) are not included and therefore cannot influence the meta-analysis results. Thus, by considering only studies with positive findings, ALE meta-analyses may carry a bias that overemphasizes the idea of structural brain changes in schizophrenia [71]. In addition, although it is known that the number of included foci affects the analyses using the ALE method, the ideal number of foci for adequate analyses is still undetermined [59].

\section{Conclusions}

In light of the current literature, despite the growing number of studies, the difficulty in reaching more incisive conclusions on this topic is still apparent. However, it seems clear that the idea of antipsychotics as potential agents contributing to the structural brain changes in schizophrenia should certainly be taken into account. These cautious conclusions are necessary based mainly on the fact that the correlations between brain volumes and antipsychotic use reported by some studies do not necessarily imply any causality [98]. Indeed, it remains elusive whether brain structural alterations in schizophrenia are due to the intrinsic pathologic process, antipsychotic use, other variables, or even a combination of all those [42].

Answering these questions is of great clinical importance. If antipsychotics really induce potentially harmful brain volumetric reductions in patients with schizophrenia, then the risks and benefits of these drugs should be carefully considered before prescription; in addition, patients should be appropriately informed about these particular risks and benefits [38]. More consistent answers could be achieved by studies with high statistical power performed longitudinally, homogeneously, with large samples, ideally multicentric. For now, some practical approaches such as closely assessing the side effects of these drugs for each patient, trying to prescribe the minimal amount that is sufficient to reach the therapeutical objectives, and also considering the inclusion of nonpharmacological treatments [114] seem adequate. For the future, we expect the research to find new drugs with distinct mechanisms of action [114] that could not only induce fewer undesirable effects but could also act on the underlying disease process rather than on just one dimension or symptom.

\section{Additional files}

Additional file 1: Details of the antipsychotic treatment employed among the subjects enrolled in the selected studies.

Additional file 2: Foci of reported brain structural changes (cluster center described in the stereotactic space: $x, y, z) *$ according to type of alteration (increase/decrease of gray and white matter) and class of antipsychotics (typicals/atypicals) in the selected studies.

\section{Competing interests}

The author declares that they have no competing interests.

\section{Authors' contributions}

UST and GFB contributed to the study design. UST and EPO contributed to the data collection. UST, EPO, SB and GFB interpreted the data and drafted the manuscript. All authors participated in critical revision of the manuscript drafts and approved the final version.

\section{Acknowledgements}

We thank Dr. Vicente Molina for kindly sharing additional information about his study.

\section{Funding}

U.S.T. is supported by a PhD grant from the Foundation for the Support of Research in the State of São Paulo (Fundação de Amparo à Pesquisa do Estado de São Paulo, FAPESP), Brazil (process 11/18631-1). G.F.B. is partly funded by Conselho Nacional de Desenvolvimento Científico e Tecnológico (CNPq), Brazil. The funders had no role in the study design, data collection and analysis, decision to publish, or preparation of the manuscript.

\section{Author details}

${ }^{1}$ Post-Graduate Program in Radiology, Institute of Radiology (INRAD), University of Sao Paulo Medical School, Sao Paulo, Brazil. 'Laboratory of Neuroimaging in Psychiatry (LIM-21), Institute of Psychiatry, University of Sao Paulo Medical School, Centro de Medicina Nuclear, $3^{\circ}$ andar, Rua Dr. Ovídio Pires Campos, s/n, 05403-010 Sao Paulo, Sao Paulo, Brazil. ${ }^{3}$ Center for Interdisciplinary Research on Applied Neurosciences (NAPNA), University of São Paulo, Sao Paulo, Brazil. ${ }^{4}$ Department of Radiology, Hospital de Base, São José do Rio Preto Medical School, Sao Paulo, Brazil. ${ }^{5}$ Department of Psychiatry, University of Basel, Basel, Switzerland. ${ }^{6}$ Department of Psychosis Studies, Institute of Psychiatry, King's College, London, UK.

Received: 22 June 2013 Accepted: 9 December 2013

Published: 20 December 2013

\section{References}

1. Ross CA, Margolis RL, Reading SA, Pletnikov M, Coyle JT: Neurobiology of schizophrenia. Neuron 2006, 52(1):139-153.

2. Tamminga CA, Holcomb HH: Phenotype of schizophrenia: a review and formulation. Mol Psychiatry 2005, 10(1):27-39.

3. Murray CJL, Lopez AD: The global burden of disease. A comprehensive assessment of mortality and disability from diseases, injuries and risk factors in 1990 and projected to 2020, GBD series Vol. I. Harvard school of public health on behalf of the world health organization and the world bank. Cambridge, Massachusetts: Harvard University Press; 1996.

4. Knapp M, Mangalore R, Simon J: The global costs of schizophrenia. Schizophr Bull 2004, 30(2):279-293.

5. Bennet L, Gunn A: The fetal origins of adult mental illness. In Early life origins of health and disease (advances in experimental medicine and biology). Edited by Wintour-Coghlan M, Owens J. New York, NY, USA: Springer; 2006:204-211.

6. Harrison PJ: Neuropathology of schizophrenia. Psychiatry 2008, 7(10):421-424.

7. Meyer U, Feldon J: Epidemiology-driven neurodevelopmental animal models of schizophrenia. Prog Neurobio/ 2010, 90(3):285-326.

8. Lawrie SM, Abukmeil SS: Brain abnormality in schizophrenia. A systematic and quantitative review of volumetric magnetic resonance imaging studies. Br J Psychiatry J Mental Sci 1998, 172:110-120.

9. McCarley RW, Wible CG, Frumin M, Hirayasu Y, Levitt JJ, Fischer IA, Shenton ME: MRI anatomy of schizophrenia. Biol Psychiatry 1999, 45(9):1099-1119. 
10. Shenton ME, Dickey CC, Frumin M, McCarley RW: A review of MRI findings in schizophrenia. Schizophr Res 2001, 49(1-2):1-52.

11. Wright IC, Rabe-Hesketh S, Woodruff PW, David AS, Murray RM, Bullmore ET: Meta-analysis of regional brain volumes in schizophrenia. Am J Psychiatry 2000, 157(1):16-25

12. Weinberger DR: Implications of normal brain development for the pathogenesis of schizophrenia. Arch Gen Psychiatry 1987, 44(7):660-669

13. Jones $P$, Murray RM: The genetics of schizophrenia is the genetics of neurodevelopment. Br J Psychiatry J Mental Sci 1991, 158:615-623.

14. Murray RM: Neurodevelopmental schizophrenia: the rediscovery of dementia praecox. Br J Psychiatry Supp/ 1994, 25:6-12.

15. Lewis DA, Levitt P: Schizophrenia as a disorder of neurodevelopment. Annu Rev Neurosci 2002, 25:409-432.

16. McGrath JJ, Murray RM: Risk factors for schizophrenia: from conception to birth. In Schizophrenia. 2nd edition. Edited by Hirsch SR, Weinberger DR. Oxford, UK: Blackwell Science Ltd; 2007.

17. Rapoport JL, Addington AM, Frangou S, Psych MR: The neurodevelopmental model of schizophrenia: update 2005. Mol Psychiatry 2005, 10(5):434-449.

18. DeLisi LE, Sakuma M, Tew W, Kushner M, Hoff AL, Grimson R: Schizophrenia as a chronic active brain process: a study of progressive brain structural change subsequent to the onset of schizophrenia. Psychiatry Res 1997, 74(3):129-140

19. DeLisi LE: Is schizophrenia a lifetime disorder of brain plasticity, growth and aging? Schizophr Res 1997, 23(2):119-129.

20. Woods BT: Is schizophrenia a progressive neurodevelopmental disorder? Toward a unitary pathogenetic mechanism. Am J Psychiatry 1998, 155(12):1661-1670.

21. Lieberman JA: Is schizophrenia a neurodegenerative disorder? A clinical and neurobiological perspective. Biol Psychiatry 1999, 46(6):729-739.

22. Lieberman J, Chakos M, Wu H, Alvir J, Hoffman E, Robinson D, Bilder R: Longitudinal study of brain morphology in first episode schizophrenia. Biol Psychiatry 2001, 49(6):487-499.

23. Pantelis C, Velakoulis D, McGorry PD, Wood SJ, Suckling J, Phillips LJ, Yung AR, Bullmore ET, Brewer W, Soulsby B, et al: Neuroanatomical abnormalities before and after onset of psychosis: a cross-sectional and longitudinal MRI comparison. Lancet 2003, 361(9354):281-288.

24. Ho BC, Andreasen NC, Nopoulos P, Arndt S, Magnotta V, Flaum M: Progressive structural brain abnormalities and their relationship to clinical outcome: a longitudinal magnetic resonance imaging study early in schizophrenia. Arch Gen Psychiatry 2003, 60(6):585-594.

25. Job DE, Whalley HC, Johnstone EC, Lawrie SM: Grey matter changes over time in high risk subjects developing schizophrenia. Neuroimage 2005 25(4):1023-1030.

26. Ashburner J, Friston KJ: Voxel-based morphometry-the methods. Neuroimage 2000, $11(6$ Pt 1):805-821.

27. Busatto GF, Diniz BS, Zanetti MV: Voxel-based morphometry in Alzheimer's disease. Expert Rev Neurother 2008, 8(11):1691-1702.

28. Ashburner J: Computational anatomy with the SPM software. Magn Reson Imaging 2009, 27(8):1163-1174.

29. Mathalon DH, Sullivan EV, Lim KO, Pfefferbaum A: Progressive brain volume changes and the clinical course of schizophrenia in men: a longitudinal magnetic resonance imaging study. Arch Gen Psychiatry 2001, 58(2):148-157.

30. Kempton MJ, Stahl D, Williams SC, DeLisi LE: Progressive lateral ventricular enlargement in schizophrenia: a meta-analysis of longitudinal MRI studies. Schizophr Res 2010, 120(1-3):54-62.

31. DeLisi LE: The concept of progressive brain change in schizophrenia: implications for understanding schizophrenia. Schizophr Bull 2008, 34(2):312-321.

32. Weinberger DR, McClure RK: Neurotoxicity, neuroplasticity, and magnetic resonance imaging morphometry: what is happening in the schizophrenic brain? Arch Gen Psychiatry 2002, 59(6):553-558.

33. Degreef G, Ashtari M, Wu HW, Borenstein M, Geisler S, Lieberman J: Follow up MRI study in first episode schizophrenia. Schizophr Res 1991, 5(3):204-206.

34. Vita A, Giobbio GM, Dieci M, Garbarini M, Morganti C, Comazzi M, Invernizz G: Stability of cerebral ventricular size from the appearance of the first psychotic symptoms to the later diagnosis of schizophrenia. Biol Psychiatry 1994, 35(12):960-962.

35. Jaskiw GE, Juliano DM, Goldberg TE, Hertzman M, Urow-Hamell E, Weinberger DR: Cerebral ventricular enlargement in schizophreniform disorder does not progress. A seven year follow-up study. Schizophr Res 1994, 14(1):23-28.

36. Nair TR, Christensen JD, Kingsbury SJ, Kumar NG, Terry WM, Garver DL: Progression of cerebroventricular enlargement and the subtyping of schizophrenia. Psychiatry Res 1997, 74(3):141-150.

37. Pantelis C, Yucel M, Wood SJ, Velakoulis D, Sun D, Berger G, Stuart GW, Yung A, Phillips L, McGorry PD: Structural brain imaging evidence for multiple pathological processes at different stages of brain development in schizophrenia. Schizophr Bull 2005, 31(3):672-696.

38. Moncrieff J, Leo J: A systematic review of the effects of antipsychotic drugs on brain volume. Psychol Med 2010, 40(9):1409-1422.

39. Scherk H, Falkai P: Effects of antipsychotics on brain structure. Curr Opin Psychiatry 2006, 19(2):145-150.

40. van Haren NE, Cahn W, Hulshoff Pol HE, Kahn RS: Schizophrenia as a progressive brain disease. Eur Psychiatry J Assoc Eur Psychiatrists 2008, 23(4):245-254

41. Navari S, Dazzan P: Do antipsychotic drugs affect brain structure? A systematic and critical review of MRI findings. Psychol Med 2009, 39(11):1763-1777.

42. Lewis DA: Brain volume changes in schizophrenia: how do they arise? What do they mean? Psychol Med 2009, 39(11):1779-1780.

43. Smieskova R, Fusar-Poli P, Allen P, Bendfeldt K, Stieglitz RD, Drewe J Radue EW, McGuire PK, Riecher-Rossler A, Borgwardt SJ: The effects of antipsychotics on the brain: what have we learnt from structural imaging of schizophrenia?-a systematic review. Curr Pharm Des 2009 15(22):2535-2549.

44. Gilbert PL, Harris MJ, McAdams LA, Jeste DV: Neuroleptic withdrawal in schizophrenic patients. A review of the literature. Arch Gen Psychiatry 1995, 52(3):173-188

45. Csernansky JG, Mahmoud R, Brenner R, Risperidone USASG: A comparison of risperidone and haloperidol for the prevention of relapse in patients with schizophrenia. N Engl J Med 2002, 346(1):16-22.

46. Meltzer HY, Alphs L, Green Al, Altamura AC, Anand R, Bertoldi A, Bourgeois M, Chouinard G, Islam MZ, Kane J, et al: Clozapine treatment for suicidality in schizophrenia: international suicide prevention trial (InterSePT). Arch Gen Psychiatry 2003, 60(1):82-91.

47. Leucht S, Barnes TR, Kissling W, Engel RR, Correll C, Kane JM: Relapse prevention in schizophrenia with new-generation antipsychotics: a systematic review and exploratory meta-analysis of randomized, controlled trials. Am J Psychiatry 2003, 160(7):1209-1222.

48. Dolder CR, Lacro JP, Leckband S, Jeste DV: Interventions to improve antipsychotic medication adherence: review of recent literature. J Clin Psychopharmacol 2003, 23(4):389-399.

49. Keefe RS, Seidman LJ, Christensen BK, Hamer RM, Sharma T, Sitskoorn MM Lewine RR, Yurgelun-Todd DA, Gur RC, Tohen M, et al: Comparative effect of atypical and conventional antipsychotic drugs on neurocognition in first-episode psychosis: a randomized, double-blind trial of olanzapine versus low doses of haloperidol. Am J Psychiatry 2004, 161(6):985-995.

50. Roth BL, Sheffler DJ, Kroeze WK: Magic shotguns versus magic bullets: selectively non-selective drugs for mood disorders and schizophrenia. Nat Rev Drug Discov 2004, 3(4):353-359.

51. Lewis DA, Gonzalez-Burgos G: Pathophysiologically based treatment interventions in schizophrenia. Nat Med 2006, 12(9):1016-1022

52. Kapur S, Agid O, Mizrahi R, Li M: How antipsychotics work-from receptors to reality. NeuroRx J Am Soc Exper NeuroTherap 2006, 3(1):10-21.

53. Arranz MJ, de Leon J: Pharmacogenetics and pharmacogenomics of schizophrenia: a review of last decade of research. Mol Psychiatry 2007, 12(8):707-747

54. Meltzer HY, Li Z, Kaneda Y, Ichikawa J: Serotonin receptors: their key role in drugs to treat schizophrenia. Prog Neuro-psychopharmacol Biol Psychiatry 2003, 27(7):1159-1172.

55. Kapur $\mathrm{S}$, Remington $\mathrm{G}$ : Dopamine $\mathrm{D}(2)$ receptors and their role in atypical antipsychotic action: still necessary and may even be sufficient. Bio Psychiatry 2001, 50(11):873-883.

56. Honea R, Crow TJ, Passingham D, Mackay CE: Regional deficits in brain volume in schizophrenia: a meta-analysis of voxel-based morphometry studies. Am J Psychiatry 2005, 162(12):2233-2245

57. Kakeda S, Korogi Y: The efficacy of a voxel-based morphometry on the analysis of imaging in schizophrenia, temporal lobe epilepsy, and Alzheimer's disease/mild cognitive impairment: a review. Neuroradiology 2010, 52(8):711-721. 
58. Turkeltaub PE, Eden GF, Jones KM, Zeffiro TA: Meta-analysis of the functional neuroanatomy of single-word reading: method and validation. Neuroimage 2002, 16(3 Pt 1):765-780.

59. Laird AR, Fox PM, Price CJ, Glahn DC, Uecker AM, Lancaster JL, Turkeltaub PE, Kochunov P, Fox PT: ALE meta-analysis: controlling the false discovery rate and performing statistical contrasts. Hum Brain Mapp 2005, 25(1):155-164.

60. Eickhoff SB, Laird AR, Grefkes C, Wang LE, Zilles K, Fox PT: Coordinate-based activation likelihood estimation meta-analysis of neuroimaging data: a random-effects approach based on empirical estimates of spatial uncertainty. Hum Brain Mapp 2009, 30(9):2907-2926.

61. Fox PT, Laird AR, Lancaster JL: Coordinate-based voxel-wise meta-analysis: dividends of spatial normalization. Report of a virtual workshop. Hum Brain Mapp 2005, 25(1):1-5.

62. Schroeter ML, Stein T, Maslowski N, Neumann J: Neural correlates of Alzheimer's disease and mild cognitive impairment: a systematic and quantitative meta-analysis involving 1351 patients. Neuroimage 2009, 47(4):1196-1206.

63. Good CD, Johnsrude IS, Ashburner J, Henson RN, Friston KJ, Frackowiak RS: A voxel-based morphometric study of ageing in 465 normal adult human brains. Neuroimage 2001, 14(1 Pt 1):21-36.

64. Talairach J, Tournoux P: Co-planar stereotaxic atlas of the human brain: an approach to medical cerebral imaging. New York: Thieme; 1988.

65. Evans AC, Collins DL, Mills SR, Brown ED, Kelly RL, Peters TM: 3D statistical neuroanatomical models from 305 MRI volumes. Proc IEEE Nucl Sci Symp Med Imag 1993, 1-3:1813-1817

66. Collins DL, Neelin P, Peters TM, Evans AC: Automatic 3D intersubject registration of MR volumetric data in standardized talairach space. J Comput Assist Tomogr 1994, 18(2):192-205.

67. Turkeltaub PE, Eickhoff SB, Laird AR, Fox M, Wiener M, Fox P: Minimizing within-experiment and within-group effects in activation likelihood estimation meta-analyses. Human Brain Mapp 2012, 33(1):1-13.

68. Lancaster JL, Tordesillas-Gutierrez D, Martinez M, Salinas F, Evans A, Zilles K, Mazziotta JC, Fox PT: Bias between MNI and talairach coordinates analyzed using the ICBM-152 brain template. Hum Brain Mapp 2007, 28(11):1194-1205.

69. Laird AR, Robinson JL, McMillan KM, Tordesillas-Gutierrez D, Moran ST, Gonzales SM, Ray KL, Franklin C, Glahn DC, Fox PT, et al: Comparison of the disparity between talairach and MNI coordinates in functional neuroimaging data: validation of the lancaster transform. Neuroimage 2010, 51(2):677-683.

70. Eickhoff SB, Bzdok D, Laird AR, Kurth F, Fox PT: Activation likelihood estimation meta-analysis revisited. Neuroimage 2012, 59(3):2349-2361.

71. Leung M, Cheung C, Yu K, Yip B, Sham P, Li Q, Chua S, McAlonan G: Gray matter in first-episode schizophrenia before and after antipsychotic drug treatment. Anatomical likelihood estimation meta-analyses with sample size weighting. Schizophrenia Bull 2011, 37(1):199-211.

72. Yu KK, Cheung C, Chua SE, McAlonan GM: Can Asperger syndrome be distinguished from autism? An anatomic likelihood meta-analysis of MRI studies. J Psychiatry Neurosci JPN 2011, 36(6):412-421.

73. Chase HW, Eickhoff SB, Laird AR, Hogarth L: The neural basis of drug stimulus processing and craving: an activation likelihood estimation meta-analysis. Biol Psychiatry 2011, 70(8):785-793.

74. Ferreira LK, Diniz BS, Forlenza OV, Busatto GF, Zanetti MV: Neurostructural predictors of Alzheimer's disease: a meta-analysis of VBM studies. Neurobiol Aging 2011, 32(10):1733-1741.

75. Massana G, Salgado-Pineda P, Junque C, Perez M, Baeza I, Pons A, Massana J, Navarro V, Blanch J, Morer A, et al: Volume changes in gray matter in first-episode neuroleptic-naive schizophrenic patients treated with risperidone. J Clin Psychopharmacol 2005, 25(2):111-117.

76. Schaufelberger MS, Duran FL, Lappin JM, Scazufca M, Amaro E Jr, Leite CC, de Castro CC, Murray RM, McGuire PK, Menezes PR, et al: Grey matter abnormalities in Brazilians with first-episode psychosis. Br J Psychiatry Supp/ 2007, 51:s117-s122.

77. Dazzan P, Morgan KD, Orr K, Hutchinson G, Chitnis X, Suckling J, Fearon P, McGuire PK, Mallett RM, Jones PB, et al: Different effects of typical and atypical antipsychotics on grey matter in first episode psychosis: the AESOP study. Neuropsychopharmacol Off Publ Am College Neuropsychopharmacol 2005, 30(4):765-774.

78. Girgis RR, Diwadkar VA, Nutche JJ, Sweeney JA, Keshavan MS, Hardan AY: Risperidone in first-episode psychosis: a longitudinal, exploratory voxelbased morphometric study. Schizophr Res 2006, 82(1):89-94.
79. Whitford TJ, Grieve SM, Farrow TF, Gomes L, Brennan J, Harris AW, Gordon E, Williams LM: Progressive grey matter atrophy over the first 2-3 years of illness in first-episode schizophrenia: a tensor-based morphometry study. Neuroimage 2006, 32(2):511-519.

80. Douaud G, Smith S, Jenkinson M, Behrens T, Johansen-Berg H, Vickers J, James S, Voets N, Watkins K, Matthews PM, et al: Anatomically related grey and white matter abnormalities in adolescent-onset schizophrenia. Brain J Neurol 2007, 130(Pt 9):2375-2386.

81. Theberge J, Williamson KE, Aoyama N, Drost DJ, Manchanda R, Malla AK, Northcott S, Menon RS, Neufeld RW, Rajakumar N, et al: Longitudinal greymatter and glutamatergic losses in first-episode schizophrenia. $\mathrm{Br} J$ Psychiatry J Mental Sci 2007, 191:325-334.

82. Stip E, Mancini-Marie A, Letourneau G, Fahim C, Mensour B, Crivello F, Dollfus $S$ : Increased grey matter densities in schizophrenia patients with negative symptoms after treatment with quetiapine: a voxel-based morphometry study. Int Clin Psychopharmacol 2009, 24(1):34-41.

83. Tomelleri L, Jogia J, Perlini C, Bellani M, Ferro A, Rambaldelli G, Tansella M, Frangou S, Brambilla P, Neuroimaging network of the Eni: Brain structural changes associated with chronicity and antipsychotic treatment in schizophrenia. Eur Neuropsychopharmacol J Eur College Neuropsychopharmacol 2009, 19(12):835-840

84. Deng MY, MCAlonan GM, Cheung C, Chiu CP, Law CW, Cheung V, Sham PC, Chen EY, Chua SE: A naturalistic study of grey matter volume increase after early treatment in anti-psychotic naive, newly diagnosed schizophrenia. Psychopharmacology (Berl) 2009, 206(3):437-446.

85. Chua SE, Deng Y, Chen EY, Law CW, Chiu CP, Cheung C, Wong JC, Lienenkaemper N, Cheung V, Suckling J, et al: Early striatal hypertrophy in first-episode psychosis within 3 weeks of initiating antipsychotic drug treatment. Psychol Med 2009, 39(5):793-800.

86. Molina V, Martin C, Ballesteros A, de Herrera AG, Hernandez-Tamames JA: Optimized voxel brain morphometry: association between brain volumes and the response to atypical antipsychotics. Eur Arch Psychiatry Clin Neurosci 2011, 261(6):407-416.

87. Molina V, Reig S, Sanz J, Palomo T, Benito C, Sanchez J, Sarramea F, Pascau J, Desco M: Increase in gray matter and decrease in white matter volumes in the cortex during treatment with atypical neuroleptics in schizophrenia. Schizophr Res 2005, 80(1):61-71.

88. Segall JM, Turner JA, van Erp TG, White T, Bockholt HJ, Gollub RL, Ho BC, Magnotta V, Jung RE, McCarley RW, et al: Voxel-based morphometric multisite collaborative study on schizophrenia. Schizophr Bull 2009, 35(1):82-95

89. Cahn W, Hulshoff Pol HE, Lems EB, van Haren NE, Schnack HG, van der Linden JA, Schothorst PF, van Engeland H, Kahn RS: Brain volume changes in first-episode schizophrenia: a 1-year follow-up study. Arch Gen Psychiatry 2002, 59(11):1002-1010.

90. McClure RK, Carew K, Greeter S, Maushauer E, Steen G, Weinberger DR: Absence of regional brain volume change in schizophrenia associated with short-term atypical antipsychotic treatment. Schizophr Res 2008, 98(1-3):29-39.

91. Frazier JA, Giedd JN, Kaysen D, Albus K, Hamburger S, Alaghband-Rad J, Lenane MC, MCKenna K, Breier A, Rapoport JL: Childhood-onset schizophrenia: brain MRI rescan after 2 years of clozapine maintenance treatment. Am J Psychiatry 1996, 153(4):564-566.

92. Lieberman JA, Tollefson GD, Charles C, Zipursky R, Sharma T, Kahn RS, Keefe RS, Green Al, Gur RE, McEvoy J, et al: Antipsychotic drug effects on brain morphology in first-episode psychosis. Arch Gen Psychiatry 2005, 62 (4):361-370.

93. Nakamura M, Salisbury DF, Hirayasu Y, Bouix S, Pohl KM, Yoshida T, Koo MS, Shenton ME, McCarley RW: Neocortical gray matter volume in firstepisode schizophrenia and first-episode affective psychosis: a crosssectional and longitudinal MRI study. Biol Psychiatry 2007, 62(7):773-783.

94. Jayakumar PN, Venkatasubramanian G, Gangadhar BN, Janakiramaiah N, Keshavan MS: Optimized voxel-based morphometry of gray matter volume in first-episode, antipsychotic-naive schizophrenia. Prog Neuropsychopharmacol Biol Psychiatry 2005, 29(4):587-591.

95. Davatzikos C, Shen D, Gur RC, Wu X, Liu D, Fan Y, Hughett P, Turetsky BI, Gur RE: Whole-brain morphometric study of schizophrenia revealing a spatially complex set of focal abnormalities. Arch Gen Psychiatry 2005, 62(11):1218-1227.

96. Tauscher-Wisniewski S, Tauscher J, Christensen BK, Mikulis DJ, Zipursky RB: Volumetric MRI measurement of caudate nuclei in antipsychotic-naive 
patients suffering from a first episode of psychosis. J Psychiatr Res 2005, 39(4):365-370.

97. Puri BK, Hutton SB, Saeed N, Oatridge A, Hajnal JV, Duncan L, Chapman MJ, Barnes TR, Bydder GM, Joyce EM: A serial longitudinal quantitative MRI study of cerebral changes in first-episode schizophrenia using image segmentation and subvoxel registration. Psychiatry Res 2001, 106(2):141-150

98. Ho BC, Andreasen NC, Ziebell S, Pierson R, Magnotta V: Long-term antipsychotic treatment and brain volumes: a longitudinal study of first-episode schizophrenia. Arch Gen Psychiatry 2011, 68(2):128-137.

99. Harrison PJ: The neuropathology of schizophrenia. A critical review of the data and their interpretation. Brain J Neurol 1999, 122(Pt 4):593-624.

100. Kubicki M, Shenton ME, Salisbury DF, Hirayasu Y, Kasai K, Kikinis R, Jolesz FA, McCarley RW: Voxel-based morphometric analysis of gray matter in first episode schizophrenia. Neuroimage 2002, 17(4):1711-1719.

101. Jayakumar PN, Venkatasubramanian G, Keshavan MS, Srinivas JS, Gangadhar BN: MRI volumetric and 31P MRS metabolic correlates of caudate nucleus in antipsychotic-naive schizophrenia. Acta Psychiatr Scand 2006, 114(5):346-351.

102. Narr KL, Bilder RM, Toga AW, Woods RP, Rex DE, Szeszko PR, Robinson D, Sevy S, Gunduz-Bruce H, Wang YP, et al: Mapping cortical thickness and gray matter concentration in first episode schizophrenia. Cereb Cortex 2005, 15(6):708-719.

103. Sigmundsson T, Suckling J, Maier M, Williams S, Bullmore E, Greenwood K, Fukuda R, Ron M, Toone B: Structural abnormalities in frontal, temporal, and limbic regions and interconnecting white matter tracts in schizophrenic patients with prominent negative symptoms. Am J Psychiatry 2001, 158(2):234-243.

104. Suzuki M, Nohara S, Hagino H, Kurokawa K, Yotsutsuji T, Kawasaki Y, Takahashi T, Matsui M, Watanabe N, Seto $\mathrm{H}$, et al: Regional changes in brain gray and white matter in patients with schizophrenia demonstrated with voxel-based analysis of MRI. Schizophr Res 2002, 55(1-2):41-54.

105. DeLisi LE, Holcomb HH, Cohen RM, Pickar D, Carpenter W, Morihisa JM, King AC Kessler R, Buchsbaum MS: Positron emission tomography in schizophrenic patients with and without neuroleptic medication. I Cereb Blood Flow Metabol Off J Int Soc Cerebral Blood Flow Metabol 1985, 5(2):201-206.

106. Wolkin A, Jaeger J, Brodie JD, Wolf AP, Fowler J, Rotrosen J, Gomez-Mont F, Cancro R: Persistence of cerebral metabolic abnormalities in chronic schizophrenia as determined by positron emission tomography. Am J Psychiatry 1985, 142(5):564-571.

107. Berman I, Merson A, Sison C, Allan E, Schaefer C, Loberboym M, Losonczy MF: Regional cerebral blood flow changes associated with risperidone treatment in elderly schizophrenia patients: a pilot study. Psychopharmacol Bull 1996, 32(1):95-100.

108. Liddle PF, Lane CJ, Ngan ET: Immediate effects of risperidone on corticostriato-thalamic loops and the hippocampus. Br J Psychiatry J Mental Sci 2000, 177:402-407.

109. Corson PW, O'Leary DS, Miller DD, Andreasen NC: The effects of neuroleptic medications on basal ganglia blood flow in schizophreniform disorders: a comparison between the neurolepticnaive and medicated states. Biol Psychiatry 2002, 52(9):855-862.

110. Baiano M, David A, Versace A, Churchill R, Balestrieri M, Brambilla P: Anterior cingulate volumes in schizophrenia: a systematic review and a metaanalysis of MRI studies. Schizophr Res 2007, 93(1-3):1-12.

111. Choi JS, Kang DH, Kim JJ, Ha TH, Roh KS, Youn T, Kwon JS: Decreased caudal anterior cingulate gyrus volume and positive symptoms in schizophrenia. Psychiatry Res 2005, 139(3):239-247.

112. McCormick L, Decker L, Nopoulos P, Ho BC, Andreasen N: Effects of atypical and typical neuroleptics on anterior cingulate volume in schizophrenia. Schizophr Res 2005, 80(1):73-84.

113. Kopelman A, Andreasen NC, Nopoulos P: Morphology of the anterior cingulate gyrus in patients with schizophrenia: relationship to typical neuroleptic exposure. Am J Psychiatry 2005, 162(10):1872-1878.

114. Lewis DA: Antipsychotic medications and brain volume: do we have cause for concern? Arch Gen Psychiatry 2011, 68(2):126-127.

doi:10.1186/1471-244X-13-342

Cite this article as: Torres et al: Structural brain changes associated with antipsychotic treatment in schizophrenia as revealed by voxel-based morphometric MRI: an activation likelihood estimation meta-analysis. BMC Psychiatry 2013 13:342.

\section{Submit your next manuscript to BioMed Central and take full advantage of:}

- Convenient online submission

- Thorough peer review

- No space constraints or color figure charges

- Immediate publication on acceptance

- Inclusion in PubMed, CAS, Scopus and Google Scholar

- Research which is freely available for redistribution 